\title{
PORNOGRAFI DALAM IKLAN: ANALISIS ISI IKLAN DALAM MAJALAH DAN TABLOID REMAJA DI INDONESIA
}

\author{
Fajar Syuderajat \\ Fakultas Ilmu Komunikasi, Universitas Padjadjaran \\ E-mail:
}

\begin{abstract}
ABSTRAK
Judul penelitian ini adalah "Pornografi dalam Iklan: Analisis Isi Iklan dalam Majalah dan Tabloid Remaja di Indonesia." Tujuan yang dirumuskan (1) mengetahui bagaimana bentuk-bentuk iklan-iklan yang dimuat dalam majalah dan tabloid remaja di Indonesia yang mengandung pornografi, (2) menggali makna di balik iklan-iklan tersebut.

Metode yang digunakan dalam penelitian ini adalah semiotika Roland Barthes. Bentuk Iklan dibagi tiga: wajah, tubuh dan bagian Tubuh.

Kesimpulan yang didapat dari hasil analisis, Bentuk iklan yang dimuat masih berada pada garis abu-abu antara pornografi dengan karya seni. Makna yang eksplisit adalah persoalan gaya hidup global sedangkan yang implisit adanya kecenderungan tindakan seksual yang permisif. Saran penelitian ini adalah pemerintah agar membuat regulasi dengan melibatkan banyak pihak sehingga nantinya undang-undang yang dihasilkan mampu dengan jelas membedakan mana bentuk yang mengandung pornografi pornoraksi dengan yang tidak. Kemudian, undang-undang tersebut dapat diterapkan secara tegas dengan dukungan hukum positif yang ada. Selain itu sangat penting juga adanya pendidikan sex bagi remaja.

Pada penelitian ini penulis mengambil beberapa sampel saja dikarenakan selama waktu survey yaitu bulan Januari hingga Maret 2015, iklan-iklan yang mengandung pornografi di majalah dan tabloid remaja masih serupa. Majalah remaja yang di ambil yaitu Seventeen dan Tabloid ialah Bintang. Mengapa Seventeen dan Bintang yang diambil karena keduanya menduduki posisi rating tertinggi bacaan remaja di Indonesia menurut Media Scene tahun 2014 yang dikeluarkan oleh lembaga riset AC Nielsen.
\end{abstract}

\section{Kata kunci:}

\section{PENDAHULUAN}

Salah satu TV swasta menayangkan tentang kasus perkosaan yang dilakukan oleh sekelompok oknum pelajar SLTP dan SLTA secara beramai-ramai di wilayah Jawa Timur. Dari hasil pemeriksaan aparat, perilaku memalukan ini akibat pengaruh dari minuman keras dan seringnya menonton VCD porno. Dalam cerita rubrik curhat (18 Mei 2001) yang lalu, ada sebuah cerita tentang seorang remaja yang menutup pintunya rapat-rapat hanya karena ingin membuka kartu remi full color yang gambarnya aduhai dan syuur. Merebaknya pornografi sungguh amat memprihatinkan, apalagi bacaan-bacaan dan sejenisnya, saat ini sangat mudah diakses oleh siapapun (termasuk remaja).

Beberapa waktu lalu survai terhadap pornografi menggambarkan bahwa banyak media massa yang masuk kategori pornografi, di dalamnya memuat isi dan gambar secara vulgar dan permisif. Banyak foto perempuan yang berpose seronok dan berpakian mini, bahkan hanya ditutupi daun pisang (Kedaulatan Rakyat), dan masih banyak kasus serupa yang seringkali masih saja menghiasi wajah media massa kita.

Situasi maraknya pornografi sebagai media yang menyesatkan hingga berimplikasi terhadap dekadensi moral, kriminalitas dan kekerasan seks yang dilakukan oleh remaja, sesunguhnya bukan sebuah kasus baru yang mengisi lembaran surat kabar ataupun media elektronik. Kasus-kasus kekerasan seksual, Kehamilan Tidak Dikehendaki (KTD) pada remaja dan sejenisnya, nampaknya masih belum banyak diangkat ke permukaan, sehingga "seolah-olah" problem ini dianggap "kasuistik" yang tidak penting untuk dikaji lebih jauh. Padahal timbulnya kasus-kasus seputar KTD remaja, kekerasan seksual, Penyakit Menular Seksual pada remaja bahkan sampai aborsi tidak lepas dari (salah satunya) minimnya pengetahuan tentang kesehatan reproduksi remaja. 
Lebih lanjut misalnya, kasus yang menimpa anak perempuan bertempat tinggal di Banten. Dia diperkosa tiga anak laki-laki di bawah umur yang merupakan tetangga korban. Ketiga pelaku dalam pemeriksaan mengaku mereka melakukan pemerkosaan karena sering menonton video porno.

Kasus lainya adalah pemerkosaan yang dilakukan Tili kepada DS, tetangga pelaku. DS suatu ketika dipanggil untuk main ke rumah pelaku. Korban yang tidak bercuriga masuk ke rumah pelaku dan di sana korban diajak pelaku untuk menonton film porno. Korban yang menolak, terpaksa menonton karena dipaksa. Seusai menonton, korban dipaksa melakukan hubungan suami-istri oleh Tili.

Pada media massa cetak kondisi yang memprihatinkan pun terjadi, terlebih ketika pintu kebebasan pers dibuka lebar. Alih-alih demi demokrasi dan kebebasan berpendapat, sejumlah media cetak ramai memuat berita, karangan, atau iklan yang menjurus pada pornografi. Dan manakala kita berbicara korban dari pelecehan seksual atau pemerkosaan usia remaja adalah usia yang rentan.

\section{Definisi Pornografi dan Pornoaksi}

Ada kesulitan dalam mendefinikan apa yang disebut dengan pornografi dan pornoaksi. Hal tersebut terjadi lantaran pornografi dan pornoaksi sangat berkaitan dengan tata nilai dari sebuah masyarakat. Maksudnya, sesuatu yang dianggap pornografi dan pornoaksi oleh masyarakat tertentu belum tentu demikian jika ditinjau dari tata nilai masyarakat yang lain.

Diana E.H. Russell, seorang feminis asal Amerika, mendefinisikan pornografi sebagai "Materi yang memenggabungkan seks dan atau eksposur alat kelamin dengan cara menyalahgunakan dan merendahkannya dalam sikap seolah mendukung, mengizinkan maupun mendorong perilaku demikian." Sedangkan secara etimologis kata pornografi berasal dari istilah Yunani kuno porne, yamg berarti perempuan budak seks, dsan graphos, yang berarti penulisan atau penggambaran tentang tindaktanduk tersebut.

Namun jika ditinjau dari kaca mata RUU Anti Pornografi dan pornoaksi Pasal 1 Ayat (1), yaitu "Pornografi adalah substansi dalam media atau alat komunikasi yang dibuat untuk menyampaikan gagasan-gagasan tentang seks dengan cara mengeksploitasi seks, kecabulan, dan/atau erotika".

Definisi pornografi dalam RUU tidak jelas karena ketiga unsur di dalamnya, yaitu eksploitasi seks, kecabulan, dan erotika, masing-masing memiliki definisi yang berbeda dan terpisah. Eksploitasi seksual, menurut LBH APIK, adalah pemanfaatan seksual manusia secara berlebihan untuk mendapatkan keuntungan baik materi atau nonmateri untuk diri sendiri atau orang lain. Kecabulan dengan mengacu pada definisi dalam Kitab Undang-undang Hukum Pidana adalah perbuatan bersifat asusila, melanggar kesopanan yang berkaitan dengan perkelaminan. Erotika adalah gairah seksual atau hal-hal yang membangkitkan gairah seksual atau kodrat alami manusia sebagai makhluk yang mempunyai gairah seksual.

Pornografi itu sendiri mengandung gambar atau cerita mengenai kehidupan pekerja seks komersial kelas bawah, kegiatan seks secara eksplisit, hal yang berkaitan kombinasi seks dan atau memaparkan alat kelamin melalui kekerasan atau sikap buruk yang mendorong dan menyebabkan terjadinya pergeseran nilai yang berkaitan dengan tindakan kekerasan, dan merupakan bentuk diskriminasi dan kekerasan seksual terhadap perempuan yang menunjukkan adanya relasi kuasa yang tidak seimbang, di mana ada pihak yang dominan dan ada pihak yang subordinat.

Pengertian pornografi dalam RUU ini juga tidak jelas di dalam definisi karena hanya menyangkut media massa (cetak, elektronik, alat komunikasi media termasuk internet, iklan komersial, iklan layanan masyarakat) dengan penekanan pada unsur publikasi sehingga bisa diartikan pornografi yang tidak dipublikasikan tidak termasuk pornografi menurut RUU ini.

Sementara di pihak lain terdapat kalangan yang pro sembari menolak pelbagai keberatan yang diajukan para ulama di atas. Mereka menilai karya itu bukanlah film porno. Tidak ada pornografi di sana. Tidak ada norma susila dan batas kesopanan yang dilanggar. Terlebih, tandas para pendukung ini, batas-batas moralitas itu tidak statis, melainkah bergerak secara dinamis mengikuti capaian peradaban umat manusia. Dan bukankah film itu tak lebih dari sebuah rekaman dari realitas pergaulan anak muda Jakarta masa kini. Secara lebih jauh, mereka 
juga berpendirian bahwa pelarangan terhadap film itu merupakan sebentuk pelanggaran dan penodaan terhadap kebebasan berekspresi dan berkesenian. Dan kebebasan berekspresi itu adalah hak asasi manusia yang dilindungi dan dijamin undang-undang.

Pro-kontra seperti ini memang tidak kunjung selesai. Tarik-menarik antara argumen agama-moralitas vis a vis kebebasan berekspresiberkesenian terus berlangsung, tanpa ada titik temu. Di satu pihak ada kaum agamawan yang hendak mengontrol ruang publik secara ketat dan kadang-kadang juga kaku. Sementara di lain pihak, terdapat sekelompok masyarakat yang hendak melabuhkan kebebasan berekspresi dan berkesenian dalam ranah publik secara totalistis, tanpa hambatan.

\section{Bentuk-bentuk Iklan Pornografi}

Secara bentuk iklan pornografi dalam konteks penelitian ini penulis membaginya menjadi 3 (tiga):

1. Gambar potret (wajah) yang menunjukan mimik atau ekspresi yang dapat menggiring pada perilaku seksual (kategori 1).

2. Gambar tubuh yang memperlihatkan bagian tubuh secara berlebihan tapi tidak memperlihatkan ekpresi atau mimik yang dapat menggiring pada perilaku seksual. Misalnya model mengenakan rok atau celana pendek sekali sehingga bagian paha hampir terlihat seluruhnya tapi model diperlihatkan sedang melakukan aktivitas umum keseharian (kategori 2).

3. Gambar tubuh yang memperlihatkan bagian tubuh secara berlebihan dan menunjukan mimik atau ekspresi yang dapat menggiring pada perilaku seksual (kategori 3).

Dari ketiga bentuk tersebut secara berurut memiliki kuantitas terbanyak yaitu bentuk 2 (dua), 1 (satu), dan 3 (tiga). Artinya bentuk yang dapat disebut sebagai iklan pornografi yang dimuat dalam majalah dan tabloid remaja masih relatif sedikit dibanding yang tidak mengandung unsur pornografi.

\section{Makna-makna Iklan Pornografi}

Pada bagian bentuk-bentuk iklan telah dapat dikategorikan 3 (tiga) bentuk yang dapat dikategorikan memiliki unsur pornografi. Dan makna-makna yang terkandung dalam iklan- iklan tersebut yaitu sebagai berikut:

a. Kategori 1 (satu):

- Makna eksplisit atau signifier: Secara apa yang nampak, kategori gambar wajah (potret) ini memperlihatkan seorang model yang difoto secara close up secara setengah menyamping, leher terlihat jelas dengan mata melirik ke kamera dan bibir dipoles gincu yang setengah terbuka.

- Makna implisit atau signified.

Iklan ini dapat diinterpretasikan: efek close up dapat memperlihatkan secra detail ekspresi dari model. Mata yang melirik kamera memberi hasil foto di mana model terlihat sedang melirik siapapun yang melihat gambar tersebut. Leher jenjang yang terbuka penuh secara close up mampu menstimulasi gairah seksual dengan menimbulkan fantasi tertentu yang merujuk bahwa leher adalah bagian organ sensitif seksual. Dan bibir yang terbuka setengah (bukan dalam ekspresi senyum) dapat diinterpretasikan pada ekspresi aktivitas seksual tertentu atau sebuah ajakan yang halus sensual terhadap aktivitas seksual.

b. Kategori 2 (dua):

- Makna eksplisit atau signifier:

Iklan yang berjudul "Main Air" ini memperlihatkan dua model remaja yang memakai rok, dan celana pendek, dengan t-shirt basah yang pada bagian perut di ikat sehingga terlihat pusar. Keduanya berpose tersenyum pada kamera. Background, batu karang besar dan percikan ombak. Setting lokasi pantai.

- Makna implisit atau signified.

Secara ekplisit sebenarnya iklan ini dikategori sebagi iklan yang mengandung pornografi karena pusar terlihat dan bagian paha hampir terlihat seluruhnya. Namun secara implisit, karena kedua model memperlihatkan ekspresi atau mimik senyum yang wajar (bukan senyum yang menggoda) dan di samping itu background, setting lokasi, dan pencahayaan (siang hari) mampu mengurangi unsur pornografi yang ada menjadi bentuk iklan tidak menstimuli atau mendorong aktivitas seksual, walaupun sebenarnya dapat juga menstimuli jika pembaca atau yang 
melihat iklan tersebut sedikit berfantasi. Namun jika berdasarkan norma pakaian tersebut kurang layak untuk ditampilkan di dalam media massa.

c. Kategori 3 (tiga):

- Makna eksplisit atau signifier:

Pada kategori 3 (tiga) ini dua pasang lelaki dan perempuan dan seorang lelaki ditengah (lima orang model). Seluruh model lelaki (tiga orang) tidak mengenakan atasan atau baju, sedangkan dua model perempuan satu mengenakan atasan t-shirt dalaman yang memperlihatkan bahu, lengan, belahan dada, dan perut (walau pusar tertutup), yang lainmengenakan jaket jeans lengan panjang dengan pose menyamping. Dua pasang model berpelukan (tubuh yang menempel satu dengan lainnya). Ekpsresi wajah dengan mata terpejam dan bibir setengah terbuka (pada model berpasangan), sedangkan model lelaki yang sendiri terlihat menunduk dengan wajah sebagian tertutup rambut. Kondisi pencahayaan yang remang-remang menampilkan efek silhouette atau bayangbayang.

- Makna implisit atau signified.

Iklan ini secara utuh mengandung unsur pornografi secara implisit walaupun secara eksplisit cara berpakain mereka masih dapat ditolerir. Mata yang terpejam, bibir setengah terbuka, dan pose yang berpelukan merujuk pada aktivitas seksual tertentu. Meskipun begitu, unsur art pada gambar iklan ini sangat kental sehingga bisa saja pembuat dan pemasang iklan dapat bersembunyi atau berdalih bahwa karya iklan tersebut adalah sebuah bentuk ekspresi dari seni fotografi.

\section{Kesimpulan}

Kesimpulan yang dapat diambil dari hasil analisis yaitu:

a. Bentuk iklan yang dimuat masih berada pada garis abu-abu antara pornografi dengan karya seni.

b. Makna yang eksplisit (signifier) adalah persoalan gaya hidup global yang merupakan bagian dari strategi besar industri modern; sedangkan yang implisit (signified) adanya kecenderungan aktivitas atau tendensi aktivitas seksual yang permisif. Misalnya dengan memperlihatkan bagian-bagian tubuh yang mampu menstimuli gairah seks atau ekspresi pose dan wajah yang memiliki tingkat seksualitas tertentu.

Dan saran-saran dari penulis yaitu:

1. Pemerintah agar membuat regulasi dengan melibatkan banyak pihak sehingga nantinya undang-undang yang dihasilkan mampu dengan jelas membedakan mana saja bentuk yang mengandung unsur pornografi pornoraksi dengan yang tidak. Dengan demikian perbedatan sesuatu mengandung unsur pornografi-pornoaksi dapat dihindari.

2. Kemudian, undang-undang tersebut dapat diterapkan secara tegas dengan dukungan hukum positifyang ada. Hal ini sangat penting karena dengan tidak adanya dukungan dari hukum positif yang berlaku, pornografi pornoaksi akan tetap saja menjadi konsumsi umum.

3. Selain itu sangat penting juga adanya pendidikan seks bagi remaja. Diharapkan pendidikan seks mampu memberikan pengetahuan yang benar tentang bagaimana aktivitas seksual dimaknai dan dilakukan sehingga perilaku menyimpang atau aktivitas seks yang tidak pada tempatnya atau terlalu dini dilakukan dapat diminimalisir.

\section{DAFTAR PUSTAKA}

Azwar, Saifuddin, 1995. Sikap Manusia Teori dan Pengukurannya. Edisi ke - 2, Pustaka Belajar, Jogyakarta.

Berger, Arthur Asa, Tanda-tanda dalam Kebudayaan Kontemporer, Tiara Wacana, Yogya, 2000.

Creswell, John W., Qualitative Inquiry and Research Design: Chosing Among Five Traditions, SAGE Publications, California, 1997.

DeVito, Joseph A., Human Communication, HarperCollins Publisher, New York, 1996.

Fisher, B. Aubrey, Teori-teori Komunikasi: Perspektif Mekanistis, Psikologis, Interaksional, dan Pragmatis, Remaja Rosdakarya, Bandung, 1990. 
Halliday, M.A.K., Language as Social Semiotic: The social interpretation of language and meaning, Open University Set Book, United Kingdom, 1993.

Jurnal Perempuan No 38, Pornografi, SMKG Desa Putera, Jakarta, 2004.

Kurniawan, Semiologi Roland Barthes, Yayasan Indonesiatera, Magelang, 2001.

Moleong, Lexi J., Metode Penelitian Kualitatif, Remaja Rosdakarya, Bandung, 1995.

Poespoprodjo, W., Logika Ilmu Menalar: Dasar-dasar berpikir logis, kritis, analitis, dialektis, mandiri dan tertib, Remadja Karya, Bandung, 1987.

Rakhmat, Jalaludin, Psikologi Komunikasi, Remadja Rosdakarya, Bandung, 1989.

Santosa, Puji, Ancangan Semiotika dan Pengkajian Susastra, Angkasa, Bandung, 1993.

Schramm, Wilbur, The Process and Effects of Mass Communication, University of Illinois Press, Urbana, 1965.

Sudjiman, Panuti, dan Van Zoest, Aart: Penyunting, Serba-Serbi Semiotika, Gramedia Pustaka Utama, Jakarta, 1992. 